\title{
Comparison of the Distribution of Heritages According to the Kuhperdata and Nias Traditions in (Siofaewali Selatan Village)
}

\author{
Bernat Panjaitan', Maya Jannah², Nimrot Siahaan ${ }^{3}$, Indra Kumalasasri $\mathbf{M}^{4}$, \\ Sriono $^{5}$ \\ 1,2,3,4,5 Law Study Program, Faculty of Law, Labuhanbatu University, Indonesia.
}

Corresponding Author: Bernat Panjaitan

DOI: https://doi.org/10.52403/ijrr.20220175

\begin{abstract}
One of the legal rules used in the process of dividing inheritance is customary law. Provisions and the existence of customary inheritance law has regulated the distribution of inheritance, in which the arrangement has accommodated the rights and obligations between the testator and his heirs. In simple terms, customary law can be interpreted as joint citizens of a legal alliance because of the similarity of residence or on the basis of descent. Customary law always prioritizes equality while still viewing togetherness as a reference in the inheritance process. The existence of customary law in the order of people's lives will always exist and continue to grow because customary law is a rule that lives and develops according to the culture and social values adopted in society. The existence of customary law after the constitutional amendment has been recognized and guaranteed its existence as stated in the 1945 Constitution Article 18 Paragraph (2) which states that the State recognizes and respects customary law community units along with traditional rights as long as they are still alive and in accordance with the development of society and the principles of the unitary state of the republic of Indonesia as regulated in law. Fair distribution of inheritance in accordance with applicable law is the basis that must be met in the distribution process. The existence of children in the distribution of inheritance has a very important position, where the presence of children will directly cause the process of inheritance between parents to their children. So that the
\end{abstract}

existence of customary law must be maintained and preserved as a culture and noble values that develop and grow in people's lives. On the other hand, understanding the position of children in the process of distributing inheritance according to the Civil Code, as well as how the process of distributing inheritance according to Nias customary law, is also very important for the author, which is the basis for conducting this research

Keywords: Distribution of heirs according to the Civil Code and Nias Customs

\section{INTRODUCTION}

The distribution of inheritance to the heirs fairly according to the applicable law is the main thing in the inheritance process, harmony, harmony and peace are the most important things that must be able to be carried out. Safety in deliberation is a basic value of togetherness in family life that must be put forward. Togetherness without having to have a dispute or dispute in the process of dividing inheritance is the most important thing, because in this case the value of togetherness and kinship should be able to become a foothold without having to prioritize the ego and interests of each party. In simple terms, an heir can be interpreted as an heir who at the time of his death leaves his assets to those who are still alive. Meanwhile, heirs are family members of the deceased who replace the position of the heir in the field of wealth law due to the 
death of the testator. While the Law of Inheritance itself is a law that regulates the transfer of assets left by someone who dies and there are consequences for the heirs. The existence of inheritance law is very important in the process of inheritance distribution, because with its existence it is able to create a legal order in people's lives.

The existence of children will directly lead to the process of inheritance between parents to their children. The transfer of inheritance from parents to their children must be carried out properly, in accordance with applicable law by prioritizing deliberation to reach an agreement. The provisions and the existence of customary inheritance law have regulated the distribution of inheritance, in which the arrangement has accommodated the rights and obligations between the heir and his heirs. One of the legal rules used in the process of dividing inheritance is customary law. In simple terms, customary law can be interpreted as a group of people who are bound by their customary law order as joint citizens of a legal alliance because of the similarity of residence or on the basis of descent.

Deliberation for consensus is the basic value that is used as the basis for the distribution of inheritance in accordance with the provisions of inheritance law. The provisions that have lived in the values and culture of the community, make the law of inheritance always obeyed and implemented. Inheritance law is a collection of regulations that regulate the law regarding wealth due to the death of a person, namely regarding the transfer of wealth left by the dead and the consequences of this transfer for those who obtain it both in their relationship with them and in their relationship with third parties.

Customary law always prioritizes equality while still viewing togetherness as a reference in the inheritance process. The existence of customary law in the order of people's lives will always exist and continue to grow, because customary law is a rule that lives and develops in accordance with the culture and social values adopted in society. The existence of customary law is used as an order and a reflection in the pattern of community behavior as a basis for noble values that are still preserved. The existence of customary law after the constitutional amendment has been recognized and guaranteed its existence as stated in the 1945 Constitution Article 18 B Paragraph (2) which states that the State recognizes and respects the units of indigenous peoples and their traditional rights as long as they are still alive and in accordance with the development of society and the principles of the Unitary State of the Republic of Indonesia, which are regulated by law. Fair distribution of inheritance in accordance with applicable law is the basis that must be met in the distribution process. The existence of customary law is one of the laws that is used as a reference and basis in the process of dividing inheritance. The existence of children in the distribution of inheritance has a very important position, where the presence of children will directly cause the process of inheritance between parents to their children. The existence of customary law must be maintained and preserved as a culture and noble values that develop and grow as a benchmark in people's lives. On the other hand, understanding how the process of dividing the inheritance according to customary law is very important for the author, which is the basis for conducting this research.

\section{METHODOLOGY}

The research method is an important factor in research in order to obtain data that is in accordance with the research objectives, it will also facilitate data development, so that the preparation of writing this law is in accordance with the scientific method. The method in this study can be detailed as follows:

The research method is a scientific activity based on certain methods, systematics and thoughts that aim to study one or several certain legal phenomena, by 
analyzing them. And an in-depth examination of the legal facts was also held to then seek a solution to the problems that arose in the phenomenon in question (Soerjono, Soerkarno).

The type of research in the preparation of this law is empirical legal research whose legal research method is a legal research method that functions to see the real law and examines the working law in the community. Because this research examines people in the relationship of life in society, the empirical legal research method can be said to be sociological legal research. It can be said that legal research is taken from the facts that exist in a society, legal entity or government agency, so that the materials are then compiled systematically, studied and then drawn conclusions.

The sources of data for this research are primary data and secondary data. Primary data taken directly from the source. In this case, it is in the form of field information from the Nias traditional leaders who are the focus of the research, relating to the legal analysis of the distribution of heirs according to the Nias Civil and Customary Code. Secondary data obtained indirectly. This data is sourced from literature books, the Civil Code, books and literature related to the distribution of heirs on the Nias tradition.

Data collection is a method used to collect data from a study consisting of:

\section{Literature study}

Literature study, namely data in a study can be in the form of data obtained from library materials.

a. Primary legal materials are statutory regulations such as the Civil Code (KUH Perdata), Nias customary books related to the distribution of heirs.

b. Secondary legal materials, namely materials that provide an explanation of primary legal materials. Secondary legal materials, including literature related to the position of children in the distribution of inheritance according to customary law.

\section{Interview}

Interviews are a way to obtain information by asking the interviewer directly. Interview is a process of interaction and communication. The results of the interviews are determined by several factors that interact and affect the flow of information. These factors are the interviewer being interviewed, the research topic contained in the list of questions and the interview situation. The interviewer submits questions to the interviewee to answer, digs deeper for answers and records the answers of the interviewees. The requirements to become a good interviewer are: Interviewing skills, high motivation and a sense of security, namely not hesitation and not afraid to ask questions. (Soemitro, 1988:57)

Data analysis is the process of organizing and sorting data into patterns, categories and basic units of description so that themes can be found and working hypotheses can be formulated as suggested by the data (Moleong 2002:103) "Quantitative Research Book. Bandung: PT. Rosdakarya Youth. The data analysis method used is qualitative analysis. Data analysis is carried out with the aim of simplifying the processed data so that it is easy to read and understand. Qualitative data analysis was carried out by testing data with concepts or theories as well as answers obtained from respondents to produce data or information in achieving harmony on the subject of the Comparison of the Distribution of Inheritance according to the Civil Code and Nias Customs in South Siofaewali Village.

\section{RESULTS AND DISCUSSION Division of Inheritance according to the Civil Code}

Brotherly relations can fall apart if the problem of distributing inheritance such as houses or land is not done fairly. To avoid problems, it is better if the inheritance distribution is done fairly. One way is to use inheritance law according to the Civil 
Code. There are two ways to inherit the right to inherit fairly, namely through absentantio inheritance and testamentair inheritance. Absenteeism inheritance is inheritance obtained under the law. In this case, the heir's relatives (the deceased who left an inheritance) are the parties who are entitled to receive the inheritance. Those who are entitled to receive it are divided into four groups, namely children, wives, or husbands of brothers or sisters, and grandfathers or grandmothers. Basically the four are the closest relatives of the heir (See Books 4 division of inheritance). Meanwhile, testamental inheritance is the appointment of heirs based on a will in this line, the heir will make a letter containing a statement about what he will want after the heir dies.

Inheritance problems usually begin to arise during the distribution and management of inheritance. For example, there are heirs who are not big hearted to receive the part that should be received or in other words want to get a more part. In order to avoid this, there are several steps that need to be taken by those of you who happen to be taking care of inheritance, especially for inheritance in the form of immovable objects (land and buildings). The first step that must be done is to make a Death Certificate in the local Kelurahan/District. After that, make a Certificate of Inheritance at the local District Court or Fatwa Inheritance at the Local Religious Court, or based on their respective Regional Regulations. In the letter/fatwa it will be stated legally and officially anyone who is entitled to inherit from the heir is mutually agreed upon and the distribution of inheritance, then the agreement must be made before a Notary. If one of the agreed distributions is the distribution of land, then you must register at the local Land Office by attaching a Death Certificate, Inheritance Certificate or Inheritance Fatwa, and a Will or Inheritance Certificate if any. One plot of land can be inherited by more than one heir. If so, registration can be carried out on behalf of all heirs (more than one name). Now, with the distribution of inheritance based on the law, it is hoped that there will be a lawsuit from one of the heirs who feels that he is not an heir in the division of the Four Entitled Groups. Receive Inheritance.

\section{GROUP I}

In this group, the husband or wife and or the descendants of the heirs are entitled to receive the inheritance. In the chart above, the inheritance is the wife/husband and their three children. Each gets share. Father mother Heir Siblings.

2. GROUP II

This group is those who get an inheritance if the heir does not have a husband or wife, and children. Thus, those who have the right are both parents, siblings, and or the descendants of the heirs. In the example above, the inheritors are the father, mother and two siblings of the inheritor. Each gets share. In principle, the parent's share should not be less than of the share.

3. GROUP III

In this group, the heir does not have siblings, so that the heir is the family in a straight line up, both from the mother's and father's lines. The example of the chart above that inherits is the grandfather or grandmother from both the father and mother. The division is divided into parts for the paternal line parts for the maternal line.

4. GROUP IV

In this group who are entitled to receive the inheritance are blood relatives in the upper line who are still alive. These They Get Share. Meanwhile, the heirs in the other line and the rank closest to the heirs get of the side. TIP Before dividing the inheritance, the heirs must first be responsible for the debts left by the testator during his life.

\section{Distribution of Inheritance According to Nias Customs}

Nias is one of the areas that uses customary law in its life. The customary law 
used comes from the rules that have been mandated by the ancestors and is the result of an agreement that was first discussed.

The people of Nias recognize several laws which are mutually supportive of the provisions to be followed, both written and unwritten laws, which in their achievement support each other. The laws that apply in Nias are:

Inheritance law is a law that regulates the inheritance of someone who has died and is given to those who are entitled, such as families and communities who are more entitled. There are three inheritance laws that apply in Indonesia, namely: customary inheritance law, Islamic inheritance law and civil inheritance law. In the Nias community, the three laws apply legally to Nias customary inheritance, those who have the right to inherit the inheritance, namely men, because the Nias tribe adheres to a patrilineal system. The Nias community recognizes several types of inheritance, namely houses for household appliances, property, gold, vacant land gardens or vacant land or land that has not been planted, customary positions and debts, that until now the indigenous people of Nias apply the hereditary system from the father's side (Patrilineal). ), which is based on blood ties according to the father's line. So that only boys become heirs, because girls are considered to have left their father's relatives, if he has married in the indigenous people of Nias, if a girl is married then it is considered to be out of her parents' kinship and into her husband's kinship. Therefore, it is understandable that the only son who continues the lineage in the Nias Indigenous community is the son, while the daughter when she is married, her kinship will pass to her husband's relatives.

The position of Nias Indigenous Men and Women in Obtaining Inheritance is as follows:

1. Position as biological child.

The position as the biological child of inheritance distribution is still based on the patrilineal system, namely boys who have the right to inherit, but now there has been a change in the mindset of giving inheritance that women also have the same rights. It's just that the acquisition of inheritance rights is not comparable to giving to men because the gift is still a gift or a gift out of love, in the form of jewelry on the condition that they participate in helping their parents earn a living for the family by working in the fields, gardens and doing housework with good.

2. Position as adopted child.

In the Nias community, adopted children are divided into two namely ono yomo or son-in-law. Adoption of adopted children because the family only has biological children who are women so that if the daughter is married, then the husband of the daughter will be made ono yomo who has rights over the biological parents of the woman. To become an ono yomo, you must follow the requirements of the community, namely the clan of the woman's parents is her clan. Besides ono yono, another term is ono nisou. Ono nisou usually exist because a family does not have a son so the family takes the child of a sibling.

Usually in the appointment of ono nisou, a traditional confirmation ceremony is held by providing pork, paying 3 fanulo or 30 grams of gold to be given to the determination of adat and the uncle (brother of Sianak's mother) and inviting all relatives and the community living in the village. At the end of the customary determination ceremony, they usually say the words of confirmation, namely Holi-holi wanuhugo sisasara todo which means that the collective agreement has become legal ono nisou and as a sign of the end of the traditional event. The distribution of inheritance to Ono Nisou if it is legal to become a child in the adopting family will be the same as the biological child of the family, even if Ono Nisou behaves well, respects the 
Bernat Panjaitan et.al. Comparison of the distribution of heritages according to the Kuhperdata and Nias traditions in (Siofaewali Selatan village).

kindness of his adoptive parents, works hard and loves his adoptive brother.

\section{Implementation of the Distribution of Inheritance to Indigenous Peoples of Nias in South Siofawali Village}

In the Nias community, when a boy marries, he usually stays at his parents' house within one, two, three years until the birth of the first child. Therefore, it is understandable that the only son who continues the lineage in the Nias Indigenous community is boys. Meanwhile, when a daughter is married, her relatives will turn to her husband's relatives, in the sense that the married daughter must leave her parents' house to follow her husband.

Inheritance is the process of transferring or transferring the inheritance of someone who has died (the heir to his heirs. In this regard, what has been described above is that in the family towards inheritance, the people of Nias adhere to a patrilineal system which is certainly related to customary law. The inheritance distribution system in Nias patrilineal society focuses more on the position of boys and other members who come from the male side.

In general, the boys themselves get the same share, this is different from before where the eldest son gets a bigger share. However, in its development and current social facts, the power of customary law in the distribution of inheritance over land has undergone a change where women are considered to have a share of the property in their family, this is due to economic progress, educational technology and socio-culture which have also caused a shift in Nias customary law in terms of distribution of inheritance over land among the Nias people.

However, the practice of applying this patrilineal family system is still common among the people of Nias, especially those who live or are domiciled in the interior as well as people who still have classical understanding and love the customary law, which places great importance on the position of men over women.

The results of the interview with the traditional leader in the village of South Siofaewali

Q: What do you think about the distribution of inheritance based on our custom, nias, sir?

$\mathrm{N}$ : Based on the provisions that we still use today, inheritance distribution is based on Nias custom, especially in Siofaewali village so far, inheritance distribution is carried out with the sipewaris and heirs community.

Q: Well, what about the heirs, sir, does the male share the same with the female?

$\mathrm{N}$ : Until now, our Nias society is still based on the patrilineal system, where the lineage is drawn based on blood relations according to the father's line, so it can be concluded that men are the only heirs while women are not, so the division of heirs in Nias custom, especially in the village of South Siofawali, women do not have the right to inherit or there are no certainties, it can be said that it is just the masi-masi (love) of their parents for them.

P: Then why can there be such a difference, sir, right with both children? why don't all get the inheritance of their parents.

$\mathrm{N}$ : Yes, it's true, they are both right, son, it's just that the difference is that the man has a very big responsibility, namely to continue the descendants or clans of his father, for example the NDRURU clan, then continuously in the family inherited by his sons, Whereas if a daughter is married, then her kinship will be transferred to her husband's relatives, that is the reason why the woman is not entitled to inherit according to Nias custom.

Q: So the distribution of heirs is carried out while the heirs are still alive, or after death, sir?

$\mathrm{N}$ : Actually the distribution of heirs is carried out while the heirs are still alive, why? Because what if the heir has died, then the distribution of the heirs will be carried 
out, then there will be many problems that will occur in the heirs.

Based on the author's analysis in this case, the distribution of heirs according to Nias custom is very much based on lineage, where lineage ties are drawn based on blood ties according to the father's line, so that boys based on Nias Dat are the only heirs while When Dian's daughter is married, her relatives will turn to her husband's relatives.

\section{Differences in the Division of Heirs according to the Civil Code and Nias Customs}

Based on the provisions of Article 852 paragraph (1) which explains that children or all of their descendants, even if they are born from other marriages, inherit from both parents, grandfather, grandmother, or all of their blood relatives in a straight line upwards, with There is no difference between a man and a woman and there is no difference based on first birth." In this case it is very different, where the explanation according to Nias custom is that the distribution of heirs is still based on lineage, where the lineage ties are drawn based on Nias custom is the only heir, while the daughter when she is married then her kinship will turn to her husband's relatives.

\section{CONCLUSION}

From the description above, it can be concluded that the implementation of inheritance in the Nias community in South Sioaeqali Village is as follows:

The procedure for distributing inheritance to the Nias community in Sioaewali Selatan Village is that inheritance or family property goes to sons or sons who already have a wife, the distribution of inheritance is only done by men (husbands or sons). man). The heirs are only attached to the son (husband) but when the husband dies, the main heir is the eldest son. A married man is called mangowalu/faoli. Meanwhile, women only get parental inheritance if all male heirs agree and the assets obtained are considered as gifts or gifts on the basis of parental mercy to daughters (masi masi zatua). Girls only get gifts from inheritance (not called heirs), even then the nature is not fixed, can be given or not.

The implementation of inheritance distribution to the Nias community in Siofaewali Selatan Village has 2 (two) stages, namely: First, when the heir is still alive. If the heir is still alive, then the heir will call the eldest child and notify that (the heir) will divide the inheritance. Because of that, the eldest son discussed it with all the heirs, then held a family discussion called huhuo yomo or huhuobambat. Next, take an agreement to hold an event called mombagi harato zatua (divide parental property), during the preparation of the event the heirs take into account the share of each heir.

1. If there is a dispute in the implementation of the distribution of inheritance to the indigenous Nias community in South Sioaewali Village, namely by holding a deliberation (mondrako) starting from the family environment and this deliberation is called orahua ziamakhelo and the result of this deliberation is called angetul zatua. If this deliberation does not reach an agreement, then a meeting is held by traditional leaders, community leaders, religious leaders who are in the village environment and this deliberation is called orahua zat, the result of this deliberation is called Angetula Zato. If in this deliberation there is also no agreement, a village meeting will be held which will be attended by families, traditional leaders, religious leaders, and community leaders by the disputing parties. help. And if an agreement is not reached, then the party who does not agree to the deliberation is ordered to settle the dispute through the Court.

\section{Acknowledgement: None}

Conflict of Interest: None

Source of Funding: None 
Bernat Panjaitan et.al. Comparison of the distribution of heritages according to the Kuhperdata and Nias traditions in (Siofaewali Selatan village).

\section{REFERENCES}

\section{Book}

1. Abdul Chaer, 2007, General Linguistics, Rineka Cipta, Jakarta.

2. Arikunto, Suharsimi. 1995, Management Research A Practical Approach, PT Rineka Cipta, Jakarta.

3. Cholid Narbuko, 1999, Research Methods, PT. Earth Literacy, Jakarta.

4. Ministry of National Education, 2007, Big Indonesian Dictionary, Balai Pustaka, Jakarta.

5. M. Ama Wohada B, 1982, Li Niha ba Li Indonesia-Nias Indonesian Language Dictionary, Serie B

6. Moleong, 2002, book qualitative research methods, PT. Rosdakarya Youth, Bandung.

7. Soemitro, Hanitijo Rony. 1988, Legal Research Methods and Jurimetry Ghalia Indonesia. Semarang.
8. Thalib Sayuti, 1985, Indonesian Family Law, University of Indonesia, Jakarta.

9. Wiradnyana, Ketut, 2010, Legitimacy of Power in Nias Culture, Indonesian Obor Library Foundation, Jakarta.

10. Zendrato, Dal, 2012, Nias Regional Grammar, Mitra Wacana Media, Medan.

\section{Constitution}

\section{Civil Code of Civil Code}

Website

11. http://tuhony.files.wordpress.com/2012/ 10/kearifan-lokal.pdf accessed on November 21, 2020

How to cite this article: Bernat Panjaitan, Maya Jannah, Nimrot Siahaan et.al. Comparison of the distribution of heritages according to the Kuhperdata and Nias traditions in (Siofaewali Selatan village). International Journal of Research and Review. 2022; 9(1): 642-649. DOI: https://doi.org/10.52403/ijrr.20220175 